Ann. Génét. Sél. anim., I977, 9 (4), 423-429.

\title{
Sensitivity of inbred Fayoumi chicks to seasonal variations
}

\author{
F. H. ABDOU, M. SOLTAN, M. ABD ELLATIF and H. AYOUB* \\ Faculty of Agriculture, Shebin El-Kom, Monofia University \\ *Faculty of Agriculture, Ain Shams University Egypt.
}

\begin{abstract}
Summary
The aim of this experiment was to study the sensitivity of inbred lines of Fayoumi chicks to seasonal variations. The results indicate that the inbred lines were more sensitive to seasonal variations than the control ones and $L_{25}$ showed the maximum responses in fertility and hatchability. The results also show that the local breed has been well adapted and often resists the harmful effect of inbreeding.

Slight inbreeding had maximum response in viability and this may be due to early homozygosity occurring in alleles responsible for viability.

For body weight, it was noticed that sensitivity of inbred lines decreased as chicks advanced in age. Therefore, these findings are important to stabilize the production of the local breed, all the year around.
\end{abstract}

\section{Introduction}

In I970 an inbreeding trial had been carried out to get different inbred lines of Fayoumi chicks. The aim of this experiment was to study the sensitivity of inbred lines to seasonal variation (i e.-winter and summer) for some economic traits of Fayoumi chicks.

\section{Material and Methods}

Full-sib, half-sib and first cousin matings were used to get different inbreeding intensities. The inbreeding coefficient percentages were $6.25,12.5,25.0$ and 37.5. The control chicks were resulted randomly from a flock mating system.

The pedigree chicks with control ones were brooded and reared during Winter I973 and Summer I974. All the experimental conditions, except seasonal variation, were the same as far as possible.

The available numbers of chicks were 956 for control and 3068 for the lines during the two years. Three pedigree pens were used for eachline. Each pen contained I5 females and one sire. The data are illustrated in Table $I$. 
TABLE I

Numbers of hatched chicks per group

Nombres de poussins éclos par groupe

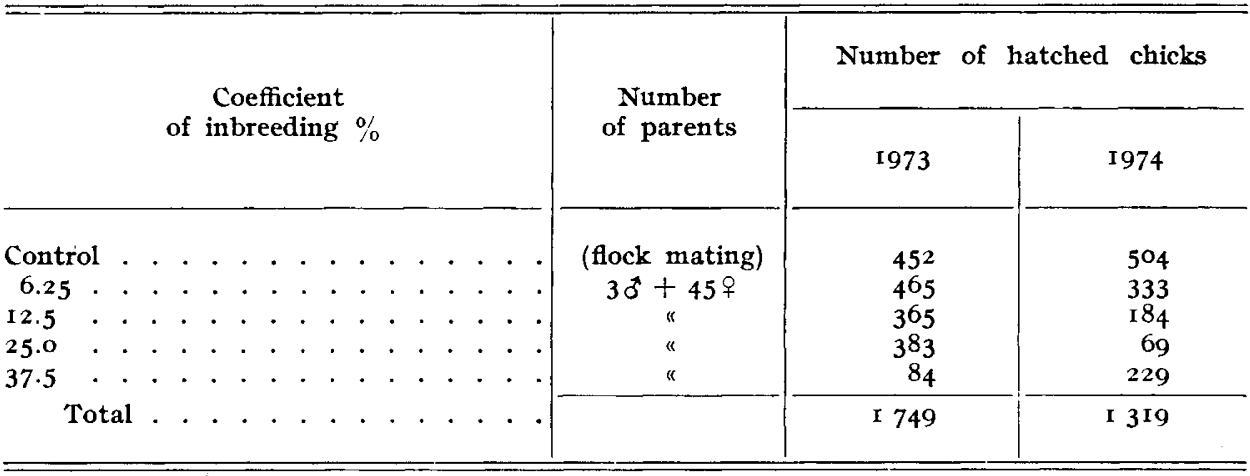

Traits studied were: fertility, hatchability, viability and body weight. All the percentage data were converted to angles with the arcsin transformation prior to statistical analysis using tables given by SNEDECOR, I959. DUNCAN's new multiple range test was also used for statistical comparisons (STEEL, and TORRIE, 1960). Corrections according to variation in control means in winter and summer were made to show the sensitivity of inbred lines to seasonal variation.

\section{Results and Discussion}

\section{Fertility}

Data presented in Table 2 show the sensitivity of inbred lines to seasonal variation for fertility. The inbred lines were more sensitive to seasonal variation than the control chicks and $\mathrm{L}_{25}$ showed the maximum response which reached $8.06 \mathrm{p}$. cent. The range of fertility percentage was 2.6 in winter, while it was 6.8 in summer. However, there were no significant differences among all the means during the two seasons. This may be due to the good adaptation of the inbred Fayoumi to our circumstances and to the harmful effect of inbreeding. This adaptation may be due to the custom of the Egyptian Farmers to raise flocks with limited numbers of cocks.

\section{Hatchability}

Inbred strain $L_{25}$ showed the greatest response to seasonal variation and its effect amounted to $8.78 \mathrm{p}$. cent in relation to winter season (Table 2 ). However, it was noticed that most of the inbred lines were less affected by seasonal variation and this may be due to the fact that proper conditions of the air draft machine were almost the same during the two seasons. Moreover, the hatching eggs in summer were not stored and set at the next day of laying. ABDou and MoukH- 
TABLE 2

Sensitivity of inbred Fayoumi lines to seasonal variation for fertility and hatchability Sensibilité de lignées consanguines de Fayoumi à une variation saisonnière pour la fertilité et l'éclosion

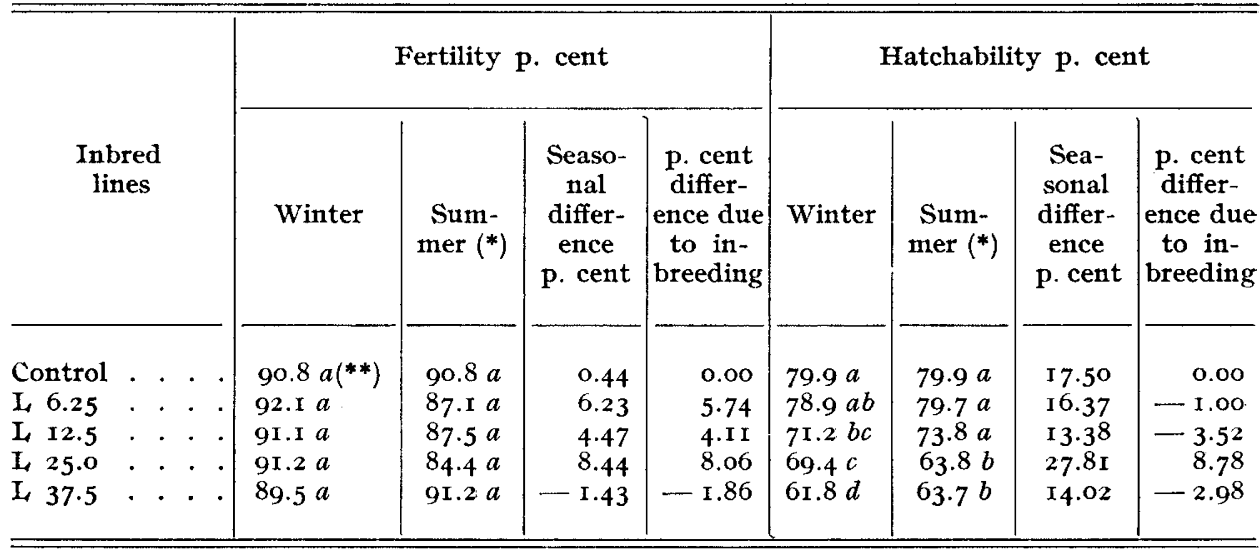

(*) After correction of seasonal effect according to control.

(**) The means not followed by the same letter are significantly different at $5 \mathrm{p}$. cent level.

TAR (I973) reported that it was possible to get reasonable hatchability $(82.2 \mathrm{p}$. cent) during June if the hatching eggs were set in the next day of laying.

DUNCAN's test of significance on transformed dams hatching percentages presented in Table 2 shows that there is no significant difference between control

TABLI: 3

Sensitivity of inbred Fayoumi lines to seasonal variation for viability at 4 and 8 weeks of age

Sensibilité de lignées consanguines de Fayoumi à une variation saisonnière pour la viabilité à 4 et 8 semaines d'âge

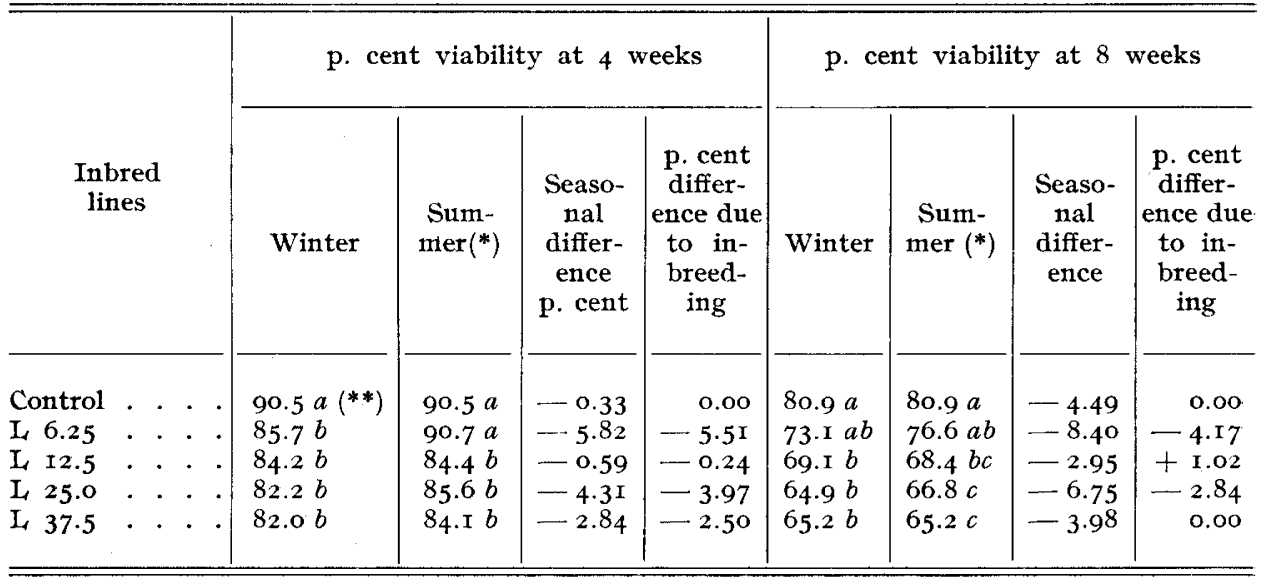

(*) After correction of seasonal effect according to control.

(**) The means not followed by the same letter are significantly different at $5 \mathrm{p}$. cent level. 
TABLE 4

Sensitivity of inbred lines to seasonal variation for viability at 12 and 16 weeks of age Sensibilité de lignées consanguines à une variation saisonniève pour la viabilité à I2 et I6 semaines d'âge

\begin{tabular}{|c|c|c|c|c|c|c|c|c|}
\hline \multirow[b]{2}{*}{$\begin{array}{c}\text { Inbred } \\
\text { lines }\end{array}$} & \multicolumn{4}{|c|}{ p. cent viability at 12 weeks } & \multicolumn{4}{|c|}{ p. cent viability at 16 weeks } \\
\hline & Winter & $\begin{array}{l}\text { Sum- } \\
\text { mer }\left(^{*}\right)\end{array}$ & $\begin{array}{c}\text { Seaso- } \\
\text { nal } \\
\text { differ- } \\
\text { ence } \\
\text { p. cent }\end{array}$ & $\begin{array}{c}\text { p. cent } \\
\text { differ- } \\
\text { ence due } \\
\text { to in- } \\
\text { breed- } \\
\text { ing }\end{array}$ & Winter & $\begin{array}{l}\text { Sum- } \\
\text { mer }\left(^{*}\right)\end{array}$ & $\begin{array}{c}\text { Seaso- } \\
\text { nal } \\
\text { differ- } \\
\text { ence }\end{array}$ & $\begin{array}{l}\text { p. cent } \\
\text { differ- } \\
\text { ence due } \\
\text { to in- } \\
\text { breed- } \\
\text { ing }\end{array}$ \\
\hline 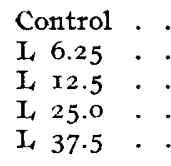 & $\begin{array}{l}76.3 a \\
66.0 a b \\
61.5 b c \\
56.4 b c \\
52.8 c\end{array}$ & $\begin{array}{l}76.3 a \\
75.6 a \\
63.2 a b \\
62.6 b \\
57.2 b\end{array}$ & $\begin{array}{rr}- & 4.15 \\
- & 16.14 \\
- & 6.53 \\
-\mathrm{I} & 3.50 \\
-\mathrm{I} & \mathrm{I} .4 \mathrm{I}\end{array}$ & $\begin{array}{r}8.00 \\
-12.70 \\
-\quad 2.69 \\
-\quad 9.90 \\
-\quad 7.69\end{array}$ & $\begin{array}{l}74.3 a \\
63.1 a b \\
57.8 b c \\
52.3 b c \\
48.3 c\end{array}$ & $\begin{array}{l}74.3 a \\
74.2 a \\
60.2 a b \\
56.8 b \\
53.7 b\end{array}$ & $\begin{array}{r}4.25 \\
-\mathrm{I} 8.58 \\
-\quad 8.1 \mathrm{I} \\
-\mathrm{I} 1.80 \\
-\mathrm{I} 3.90\end{array}$ & $\begin{array}{r}0.00 \\
-14.96 \\
-\quad 3.99 \\
-\quad 7.92 \\
-10.06\end{array}$ \\
\hline
\end{tabular}

(*) After correction seasonal effect according to control.

(**) The means not followed by the same letter are significantly different at $5 \mathrm{p}$. cent level.

and slightly inbred line during both seasons. The marked difference was observed between $L_{12.5}$ and $L_{25}$, the latter being more affected by seasonal variation. In winter season there was no significant difference between them, while it was significant in summer.

It was of interest to notice that intensive inbreeding ( $\mathrm{L}$ 37.5) showed less variation and this may be due to the type of gene action in which homozygosity occured. Moreover, these results reveal again good adaptation of the local breed and its homeostasis.

\section{Viability}

Data presented in Tables 3 and 4 indicate that seasonal variation of the inbred lines for viability increased as chicks advanced in age. The seasonal differences in control chicks were $-0.33 \mathrm{p}$. cent and $-4.49 \mathrm{p}$. cent at 4 and 8 weeks of age, while these figures in the inbred lines ranged from -0.59 to -5.82 and -2.95 to -8.40 , in the same order. The seasonal differences at $\mathrm{I} 2$ and $\mathrm{I} 6$ weeks were -4.15 and -4.25 in the control and ranged from -6.53 to - I6.I4 and from 8.II to $-\mathrm{I} 8.58$ in inbred lines, respectively. After substracting seasonal effect from total differences to get net difference due to inbreeding, it was noticed that $\mathrm{L}_{6.25}$ gave the maximum response. This corresponds to the great differences between its viabilities in winter and summer. In winter the difference between $\mathrm{L}_{6.25}$ and control chicks was larger than its corresponding in summer. Moreover, the viability means of $L_{6.25}$ was more nearly related to the control means in summer than in winter. DuncaN's test showed the same trend where $\mathrm{L}_{6.25}$ in winter was more related to intensive inbreeding lines, while in summer it was more related to 
TABLE 5

Sensitivity of inbred Fayoumi lines to seasonal variation for body weight (unweighted means of both sexes) at 4 and 8 weeks of age

Sensibilité de lignes consanguines de Fayoumi à une variation saisonnière pour le poids corporel (moyenne non pondérée des deux sexes) à 4 et 8 semaines d'âge

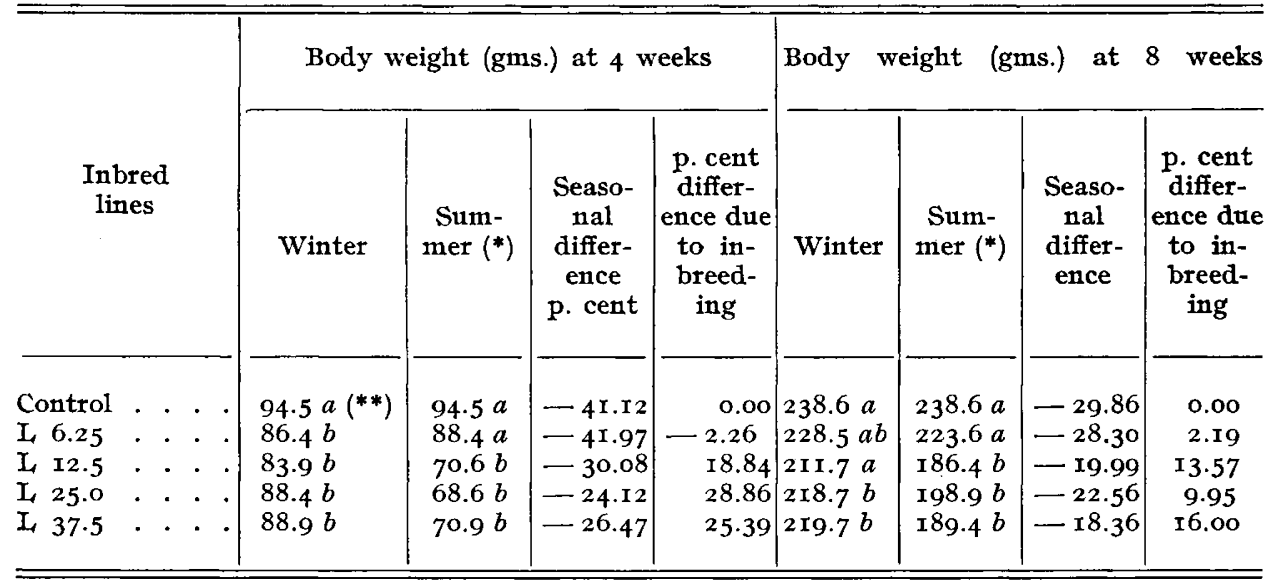

(*) After correction seasonal effect according to control.

${ }^{* *}$ ) The means not followed by the same letter are significantly different at $5 \mathrm{p}$. cent level.

control. These results indicate that slight inbreeding had maximum effect and this may be due to early homozygosity occured in alleles responsible for viability.

Low total seasonal variation of viability at earlier ages may be due to heating system in brooding period which was almost the same during the two seasons. Therefore, after 8 weeks of age seasonal effect was more clear as chicks grew older and heating stopped.

Duncan results reveal these findings where the differences among the means at earlier ages were somewhat the same during the two seasons. At older ages, these differences largely differed from winter to summer.

These results indicated the sensitivity of the inbred line viability to seasonal variation, while the control chicks were less affected.

\section{Body weight}

The demand for poultry meat all the year around calls special consideration to seasonal variation in chicken raising. Therefore, seasonal effect and its interaction with the type of gene action in Fayoumi chickens are important from the economical viewpoint. Moreover, most of the local flocks are almost closed and having a limited number of cocks and inbreeding often occurs. Seasonal differences in the control chicks were 4 I.I2, 29.86, 20.88 and 8.84 , at $4,8,12$ and I6 weeks (Tables 5 and 6 ). It was clear that seasonal differences decreased as chicks advanced in age, and this may be due to genetic homeostasis in local breed. ABDOU (Ig64) reported that seasonal variation in control chicks was $23 \mathrm{p}$. cent at I6 weeks of age. 


\section{TABLE 6}

Sensitivity of inbred Fayoumi lines to seasonal variation for body weight (unweighted means of both sexes) at 12 and 16 weeks of age

Sensibilité de lignées consanguines de Fayoumi à une variation saisonnière pour le poids corporel (moyenne non pondérée des deux sexes) à I2 et à I6 semaines d'âge

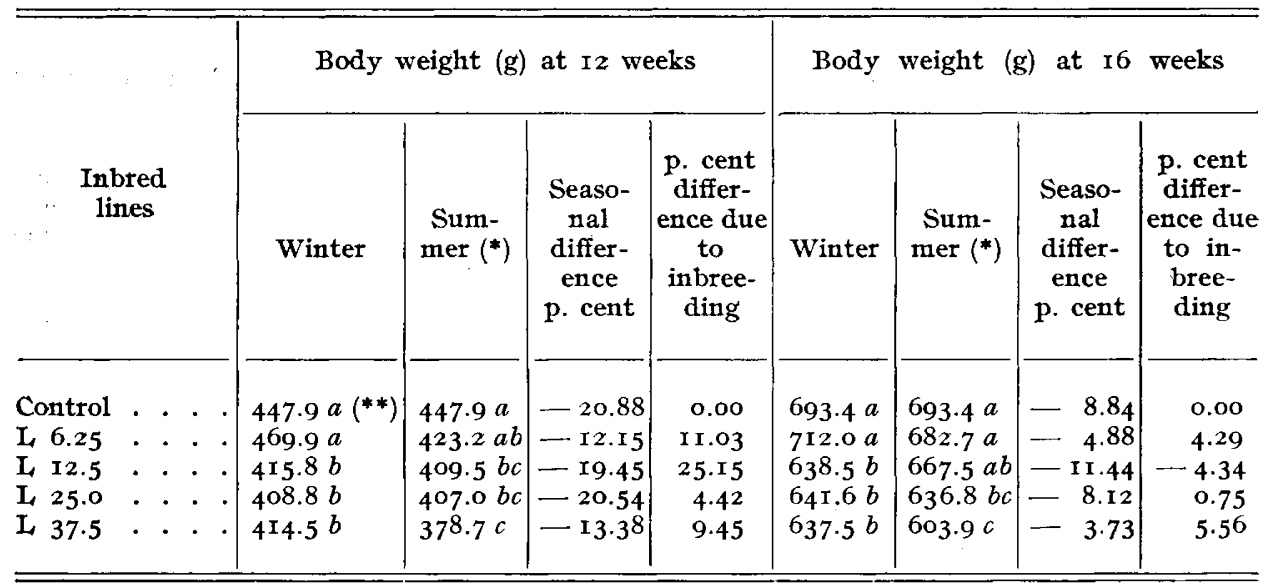

(*) After correction for seasonal effect according to control.

$(* *)$ The means not followed by the same letter are significantly different at 5 p. cent level.

Data presented in Tables 5 and 6 show that sensitivity of inbred chicks decreased as chicks advanced in age. It may indicate that alleles responsible for early growth rate were more sensitive to seasonal variations. This setsitivity in early age corresponded to great differences between the means of the two seasons. Duncan's tests revealed these findings where the differences among the means, at earlier ages were nearly the same during the two seasons. At older ages, these differences differed largely from winter to summer.

Therefore, these findings are important to stabilize the production of local breed all the year around.

Rę̧u pour publication en décembre 1977.

\section{Résumé}

\section{Sensibilité de poulets Fayoumi consanguins à des variations saisonnières}

Le but de cette expérience était d'étudier la sensibilité de poulets de lignées consanguines de Fayoumi à des variations saisonnières. Les résultats indiquent que les lignées consanguines étaient plus sensibles à ces variations que la population témoin et que la lignée L/25 montrait la réponse maximum pour la fertilité et l'éclosion. Les résultats montrent aussi que la race locale est adaptée et résiste souvent à l'effet dépressif de la consanguinité.

Une consanguinité légère donne également la réponse maximum pour la viabilité; 'ceci peut être dû à l'apparition d'une homozygotie pour dès allèles affectant ce caractère.

Pour le poids corporel, la sensibilité des poulets consanguins décrôit avec leur âge. Ces résultats sont importants en vue de stabiliser la production de la race locale tout au long de l'année. 


\section{Références}

ABDou F. H., 1964. The effects of crossbreeding on meat yield of Fayoumi chickens. M. Sc. Thesis, Univ. of Alexandria.

ABdoU F. H. and Moukhtar ABDELIATIF, 1973. Effect of preincubation storage period of hatching eggs on hatchability and post-hatching body weight of Fayoumi chickens. Ann. Agric. Sci. (in press).

SNEDECOR G. W., I959. Statistical methods. The Iowa State College Press, Ames, U.S.A., STEEL, G. D. and J. H. TORRIE, r960. Principles and procedures of statistics. McGraw Hill, New York, U.S.A. 